\title{
Comments on the Publication
}

of Munich Nomenclature III by the Cytology Coordination Conference

\section{Stellungnahme zur Veröffentlichung der „Münchner Nomenklatur III“ von der Koordinations-Konferenz Zytologie}

Authors

Affiliations
A. Schneider ${ }^{1}$, P. Hillemanns ${ }^{2}$

1 Institut für Zytologie und Dysplasie, Berlin

2 Universitäts-Frauenklinik, Hannover
Deutschsprachige Zusatzinformationen online abrufbar unter: www.thieme-connect.de/ ejournals/toc/gebfra
Bibliography

DOI http://dx.doi.org/

10.1055/s-0034-1368228

Geburtsh Frauenheilk 2014; 74 :

242-243 @ Georg Thieme

Verlag KG Stuttgart · New York . ISSN 0016-5751

\section{Correspondence}

Prof. Dr.

Achim Schneider M.P.H.

Medizinisches Versorgungs-

zentrum im Fürstenberg-Karree Berlin

Institut für Zytologie und Dysplasie, Berlin

Hohenzollerndamm 123

14199 Berlin

schneider@izd-berlin.de
The Bethesda system (TBS) for the classification of Pap smears was introduced in 1988 because, at the time, several different classification systems were being used in parallel, leading to greater numbers of unspecific diagnoses requiring subsequent triaging and resulting in higher costs. The TBS was revised in 1991 and in 2001; it has been used in the USA and many other countries since 12 years and has not been revised since then.

The German Cytology Coordination Conference (KoKoZyt) has translated the TBS into German to bring the cytological nomenclature used in Germany into line with international terminology; it is referred to as "Munich Nomenclature III for the Cytological Diagnosis of Cervical Pap smears, as of 1 July 2014 ([1], cf. http://www.ag-cpc.de, website of the German Society for Cervical Pathology and Colposcopy). We welcome this approach as this permits international comparisons of findings.

However, the authors have concluded that

1. the revised version for Group II will improve the sensitivity of the detection of cervical intraepithelial neoplasias and glandular cervical neoplasias without decreasing the specificity,

2. it will improve the communication of cytological findings among cytologists, gynecologists and their patients,

3. the quality of care offered to patients will improve as unnecessary follow-up examinations and therapies will be avoided, and

4. it will be possible to reduce the subsequent costs of preventative cervical cancer screening. The Bethesda system has been used in the USA for 25 years and there is not a single study which has evaluated any one of these 4 points listed in the "Conclusions to Munich Nomenclature III". According to personal communications by wellknown American researchers who have worked extensively on TBS such as Diane Solomon [2], Walter Kinney, Mark Stoler and Massad Stewart [3], such studies have not been and will not be carried out.
We therefore suggest that the authors remove the "Conclusions" and develop a scientific concept which can be used to show whether the abovelisted 4 hypotheses can be proven.

Each of the 19(!) possible diagnostic groups listed in Munich Nomenclature III is accompanied by recommendations which are peppered with terms such as "as the case may be", "possibly", "and/or", "in special cases', "additive methods". The TBS includes no recommendations whatsoever; our colleagues in the USA who have been using the TBS since 1988 can refer to consensus guidelines which are regularly updated, most recently in 2012, and which offer recommendations on how to examine and treat different TBS groups. In these guidelines, the 10 TBS groups used to describe epithelial changes (compared to 17 (!) groups in Munich Nomenclature III) are divided into additional subgroups for

- women aged between 21-24 years and between 30-64 years,

- pregnant women,

- postmenopausal women,

- women with positive or negative HPV results or who tested positive for HPV-16 or -18 , and

- women with a previous history of cytologically abnormal smears.

The consensus guidelines conclude that "electronic medical records and computers hold great promise for assisting clinicians and patients in negotiating the complexity" of the many different potential options.

We therefore propose that Munich Nomenclature III should be simplified in analogy to the TBS and that all recommendations should be removed. An S3 Guideline "Prevention of Cervical Cancer" is currently being compiled with differentiated and practicable recommendations for the respective diagnoses which also take account of the specific framework of our healthcare system (including the use and availability of biological markers, experience with colposcopy, the expectations of pa- 
tients, and laws). Classification systems such as the TBS or Munich Nomenclature III remain unchanged for several decades while guidelines are reviewed and modified every 2 years.

\section{Conflict of Interest}

The authors received financial support from Karl Storz, Tuttlingen, in the form of funding for equipment, fellowships for former colleagues and, until 2013, scientific consultancy services.

\section{References}

1 http://www.ag-cpc.de/media/131218-mnomenklaturiii.pdf

2 Solomon D, Schiffman M, Kurman R et al. The 2001 Bethesda system: terminology for reporting results of cervical cytology. JAMA 2002; 287: 2114-2119

3 Massad LS, Einstein MH, Huh WK et al. 2012 updated consensus guidelines for the management of abnormal cervical cancer screening tests and cancer precursors. Obstet Gynecol 2013; 121: 829-846 